UDC 821.111

DOI 10.22455/2541-7894-2019-7-186-201

\title{
Michael ALEXANDER
}

\section{WHAT EZRA POUND MEANT TO ME}

Abstract: The memoir about personal meetings with Ezra Pound in Rapallo in 1962 and 1963, at T. S. Eliot's memorial service in London in 1965, and finally in Venice in the later 1960s, dwells also on the reception of the poet's work in postwar Britain and in the USA. In the 1960s England largely forgot Pound; his role was historic, his name and his presence faded: in a version of literary history current in British universities in 1960, Ezra Pound figured as "the precursor of Eliot". In the USA, on the contrary, his breakthrough in modernist poetry as well as his anti-Semitism and admiration for Italian Fascism were well recognized, thanks to the controversy over the award of the Bollingen Prize to Pound's Pisan Cantos. The memoir shows how a name from literary history becomes a part of personal experience after meeting the man himself, and how it leads to a new understanding of the poet's legacy - against wider historical, cultural, and literary background. The memoir also provides interesting facts that stimulate reflections on the literary canon, its constant change and flux despite its apparently stable nature.

Keywords: memoir, Ezra Pound, T.S. Eliot, Olga Rudge.

(C) 2019 Michael Alexander (translator, poet, Professor Emeritus, University of St Andrews, Scotland)michael.j.alex@gmail.com 
УДК 821.111

DOI 10.22455/2541-7894-2019-7-186-201

\section{МайкЛ АЛЕКСАНДЕР}

\section{ЭЗРА ПАУНД В МОЕЙ ЖИЗНИ}

Аннотация: Публикация представляет собой мемуарный материал, в центре которого - личные воспоминания о встречах с Эзрой Паундом в Рапалло в 1962 и 1963 гг., на похоронах Т.С. Элиота в Лондоне в 1965 г. и в Венеции в конце 1960-х. Автор также касается рецепции творчества Паунда в Британии и США в 1960-х гг. В Англии Паунд оказался практически забыт: о нем воспоминали лишь как о фигуре из исторического прошлого, его имя поблекло, его живое присутствие не ощущалось. В той версии литературной истории, которая была в ходу в британских университетах в 1960 г., Паунд фигурировал исключительно как «предтеча» Элиота. Напротив, в США хорошо помнили как революцию, совершенную им в модернистской поэзии, так и его антисемитские взгляды и его поддержку итальянского фашизма не в последнюю очередь благодаря скандалу вокруг присуждения Паунду Боллингеновской премии за «Пизанские кантос». Мемуары показывают, как имя из литературной истории становится частью собственного опыта после личного знакомства с поэтом и ведет к новому постижению его наследия в широком историческом, культурном и литературном контексте. Воспоминания также дают интересный материал для размышлений о природе литературного канона, который подвержен постоянному изменению и пересмотру, несмотря на свою кажущуюся устойчивость.

Ключевые слова: мемуары, Эзра Паунд, Т.С. Элиот, Ольга Радж.

(c) 2019 Майкл Александер (переводчик, поэт, почетный профессор Университета Сент-Эндрюс, Шотландия) michael.j.alex@gmail.com 
I first read a poem by Ezra Pound when I was twelve, in the class of an English teacher, Peter Whigham, an admirer of this American poet. Whigham was teaching at a preparatory school, a school for boys to the age of 13. On leaving secondary school in 1959, I chanced to meet my old teacher again. A poet, he encouraged my poetic ambitions, and introduced me to the full range of Pound's work, and that of other American poets, notably that of William Carlos Williams. Whigham, an Englishman, had an American mother. A translator as well as a poet, Whigham's verse Catullus is still in print in Penguin Classics.

In English universities in 1960, Ezra Pound was a name from the literary history of the period before the First World War. He was best known as the dedicatee of The Waste Land. The better-informed might know that he was the inventor of Imagism, the champion of Eliot and Joyce, the secretary of W.B. Yeats. In pre-First World War London, for the younger generation, Ezra Pound was a man who knew about poetry, the man who modernised poetry. Some editors printed what he told them to print, and the course of English and American poetry changed. Pound was listened to. But the 1914 war had driven this colourful, entertaining American to raise his voice, finding himself more and more on the margin of London literary life, insofar as that life continued. In 1920, after twelve years residence, Pound shook the dust of London from his feet. He returned only twice: in 1938, to attend to his wife's family's affairs; and in 1965 for Eliot's memorial service. England largely forgot him; his role was historic, his name and his presence faded. Eliot loyally published Pound's poetry and much of his prose, but otherwise, as far as literary London was concerned, Pound had (as he wrote of his fictional poet Hugh Selwyn Mauberley) "passed from men's memory."

Of the roles of these two American poets in the modernist revolution, Pound wrote later, that he, Pound, had smashed in the front door while Eliot nipped round the back and collected the swag. These American burglaries caused some resentment among the natives. Eliot's rapid ascent to critical authority in the London literary scene of the 1920s was not due only to the impact and the merits of The Waste Land and the acumen of Eliot's critical essays. His ascendancy coincided with the maturing of English as a major university subject, notably at Cambridge, where I.A. Richards and F.R. Leavis championed Eliot as poet and as critic. The word was passed around, and Eliot entered the English literary canon and shaped its future. 
Pound, in a version of literary history current in British universities in 1960, figured as the precursor of Eliot. There was no god but Eliot, and Ezra was his prophet. Eliot had adopted English protective colouring to become "more English than the English", whereas Pound was defiantly and idiosyncratically American. Eliot became editor of The Criterion and poetry editor at "Faber and Faber". Pound was "abroad", prophesying from afar. Resident in Italy from the beginning of the Fascist period, he was an admirer of Mussolini and a critic of the capitalist democracies, especially that of London. After the USA declared war on the Axis and therefore on Italy, Pound tried to return to the US but was refused a visa by the American authorities. He broadcast on Rome Radio a series of talks, some on literature, others opposing US involvement in the war, and urging US soldiers not to fight against Italy. These sincere but rash and highly idiosyncratic broadcasts were disfigured by outbreaks of virulent anti-Semitism. Handed over to US forces when they reached Rapallo, Pound was flown back and charged with treason. Adjudged unfit to stand trial, he was committed to a Washington mental hospital for the criminally insane, St Elizabeths. There he remained until the charge was dropped in 1958. He returned to Italy, where he lived until 1972. From before the First World War until about 1960, Pound's chief preoccupation was writing and extending his Cantos.

As an undergraduate at Oxford from 1959 to 1962 I frequently brought Ezra Pound's opinions into my essays and conversation. No one else ever mentioned him, least of all my tutors, whose teaching responsibilities barely included the literature of the early twentieth century. A fellow student showed me an issue of the classical journal Greece and Rome with an article which began by referring to "the late Mr Pound". I wrote to the editor, who replied that he was "disconcerted to learn that Mr Pound was still alive." The contributor to Greece and Rome, L.P. Wilkinson, confessed to the factual errors I had pointed out in my "Letter to the Editor", adding that he had received many letters asking why he had brought the name of Pound into a serious classical journal. I remember only one Oxford undergraduate, of Italian descent, objecting to Pound's economics, his admiration for Italian Fascism or his anti-Semitism. These were well known in the USA, thanks to the controversy over the award of the Bollingen Prize to Pound's Pisan Cantos. The Jewish dramatist Arthur Miller had described Pound as "worse than Hitler". 
What did Pound mean to me in my undergraduate days? I enjoyed his fresh voice, his iconoclastic criticism, his cheerful dismissal of old orthodoxies. He was fun to read. I admired the beauty of Cathay and the extraordinary deftness of some of his "Imagisms". I appreciated his Mauberley and his Propertius. I was also stimulated by, and learned much from, his enthusiastic advocacy of classical and romance-language authors, notably Homer, Catullus, the troubadours, Dante, Villon. I applied my little Latin, Greek, French and Italian to explore these authors, and Pound introduced me to versions of Chinese poetry. The Oxford English syllabus, and, so far as I met them, the membership of the Oxford English Faculty of those days, was historical and somewhat dusty. I enjoyed all the reading I had to do there, and getting to know Old English poetry, but I learned rather little (I had read nearly all of the non-medieval part of the Oxford syllabus in ten terms in the sixth form at school). Apart from William Cookson, the editor of Agenda, I found no undergraduate who admired Pound or knew much about him. Cookson published my first translations in Agenda, his little poetry magazine, a very Poundian magazine which later kept the flag of poetic modernism - with notable contributions by David Jones and later by Geoffrey Hill - flying in London.

To Cookson himself, Ezra Pound was something of a father figure, his own father having died when Cookson was an infant. For me, Pound was a stimulus to explore non-English literature. With no great interest in politics, I did not then realise that Cookson shared many of Pound's angry sympathies. I found the Cantos difficult, since they often concerned things I knew little or nothing about, though I also found them mysteriously inviting, and they offered glimpses of green oases - Homeric, Chinese, Mediterranean. My own verse translations of Old English gradually became less marked by Pound's example, and, as I matured, my admiration for Pound's work took its place among wider perspectives, and I began to discriminate within it. I did not admire Pound's prose from the mid-thirties onward, beginning with Guide to Kulchur, and I could make little of his economic theories. But what began to loosen Pound's influence on my thinking and practice was meeting the man himself shortly after I left Oxford. 


\section{$* * *$}

I met Pound several times in the 1960s, first in Rapallo in 1962 and 1963; at T.S. Eliot's memorial service in London in 1965; and finally in Venice in the later 1960s. I reported things he had said to me in two books, The Poetic Achievement of Ezra Pound (Faber and California University Press, 1979; Edinburgh University Press, 1998), and a jointly-edited collection, Sons of Ezra: British Poets and Ezra Pound (Rodopi, Amsterdam/ Atlanta, 1995). But a fuller account of these visits, based on diaries of the time, may be worth setting down for the purposes of historical record.

The purpose of my 1962 visit was to ask the translator of the Old English "Seafarer" if he would accept the dedication of a book I was engaged upon, called The Earliest English Poems. This had been commissioned in 1959 by Peter Whigham, who had introduced his classes to some of Pound's "Epitaphs", poetic jokes which appealed to the young:

$\mathrm{Fu} \mathrm{I}$

Fu I loved the high cloud and the hill, Alas, he died of alcohol.

Li Po

And Li Po also died drunk.

He tried to embrace a moon

In the Yellow River.

In 1959, Whigham introduced me to Pound's "Seafarer", a translation I admired. As I was to study Old English in my degree course at Oxford, Whigham suggested that I should make verse translations of a selection of the shorter poems in Old English. Indeed - a Poundian gesture - he commissioned me to do such a book, offering the extraordinarily generous "advance" of £100. The resulting book, The Earliest English Poems, was eventually published in 1966 by Penguin Classics. It is still in print; the latest edition is called The First Poems in English. Together with my later version of Beowulf, these verse translations have sold a million copies.

As The Earliest English Poems progressed, I wrote to Pound at Brunnenburg, the castle in the Italian Tyrol belonging to Boris de Rachewiltz, the husband of Pound's daughter, Mary. Pound had left the castle, and it was his 
wife, Dorothy Shakespear Pound, who replied: "I opened your letter to my husband and am forwarding it to him near Rapallo, where he is staying with a friend... The address to find him is 131 Sant' Ambrogio / (above) Rapallo, Liguria... At the end of Aug. he will have to have a second operation." And so my visit was arranged.

At Rapallo, in the late summer of 1962, I started up the steep path to Sant' Ambrogio, through terraces of olive trees. I soon overtook an older Italian woman carrying her shopping up the hill, but ten minutes later she overtook me. It was warm. I found 131 Sant' Ambrogio, a small white house to the right of the path, below the church of St Ambrose. The lady who opened the door looked Italian and I assumed that the syllables she now addressed to me belonged to the Italian language: Mi stair bio woove. The vowels were Italian, but the speaker, I realised when she added "Mister Beowulf, I presume," was an American. This was Olga Rudge, the friend of Dorothy Pound's letter.

Miss Rudge welcomed me but explained that Mr Pound was in bed. I had not thought about Pound's very recent operation, its nature and possible seriousness (a prostatectomy, I learned much later). I was expected and had come from far, but a morning visit could not have been convenient so early in a convalescence. It was good of them to welcome me. Miss Rudge had said, before opening the door to the bedroom, that Pound suffered from "pressure of thought". "He never did speak much," she added, "Only to the dog."

A small white room with a bed and a chair. The window looked down to the blue bay of Rapallo. Pound, who was 76, looked much older than he had in the last photograph of him I'd seen, taken on his return to Italy in 1958/9. The cover of G.S. Fraser's paperback Ezra Pound showed an active, energetic figure. Here, now, was the author of the poems and translations I admired. The head lying back on the pillow was fine, the face much wrinkled, the eyes milky and remote. He was tired, even frail, and seemed more aged than anyone I had so far met face to face in my twenty-one years. That face was to be much photographed but I was perhaps the first English visitor to see this drastically revised Ezra Pound.

A firm handshake, and I asked: "Are you on the mend?" EP: "Possibly. One can't tell."

MA: "I bring good wishes from Peter Whigham." 
Whigham had visited Pound in St Elizabeths, the Washington mental hospital where Pound was confined from 1946 to 1958 . Whigham had transcribed some papers of Randolph of Roanoke for Pound; and had argued for the poet's release. To this greeting Pound made no reply but gazed out of the window. The silence lengthened. I observed that it was quiet and peaceful up there in the house.

EP: "Quiet ... and peace..." - longer pause - "do not mean" - pause "the same thing."

This was uttered wearily in his distinctive cadence, and his voice had its unique American timbre. I remembered the voice, and the Aged Sage aphorisms, from the three television interviews at Brunnenburg that D.G. Bridson had made for the BBC two years earlier.... Recalling the purpose of my visit, I asked if he would accept the dedication of the book, The Earliest English Poems.

EP: "If you think ... it can be done ... without EIR-RONEIGH."

Lost for a reply, I asked "Do you write much?" "Very little."

Eyes on the window, stony. These exchanges - Pound did not always put the ball back across the net - may not have taken many minutes, though the time seemed long to me, and probably to him. The young may not appreciate that invalids tire easily. It was by now late morning.

Olga Rudge kindly asked me back to supper in the evening of the following day. Before going to dine with them, I had followed their recommendation and walked a few miles round the crest of the hills above Rapallo. On arrival, I presented my hostess with a bottle of Asti Spumante. "But this is wine for a celebration, capito." There was nothing to celebrate.

At dinner, however, Pound was more cheerful. He asked how Peter Russell was getting on with his bookshop, and spoke of Boris de Rachewiltz's book on African Art; and of Frobenius. When Olga Rudge was out of the room I asked him about further Cantos. "I've a few fragments, but I can't make much sense of them, and nobody else can." Then: "She's kept me alive, and no-one will thank her for it." Pound's self-confidence had gone. 
I had sent him my first translations, of "The Ruin" and "The Wanderer". EP: "There's a start. The coherence is there. Several unambiguous phrases. Something valid. Complete, perfect.... Your BAATH poem is very fine" ('The Ruin', set in Roman Bath). Well, if 'The Seafarer' was a start, you ..."'

EP: "She makes me read to her."

EP, on discovering my Catholicism: "St Peters was built with taxes. The Church makes that distinction, between a loan which yields profit, and a loan which does not yield profit. That being so, why are all the churches in Canada mortgaged?"

Did I know Fr Desmond Chute, a priest in Rapallo, who had recently died? Chute had been a close associate of Eric Gill in the Guild of St Dominic and St George at Ditchling in Sussex. Pound spoke much of Fr Chute, and of his "very fine" portraits of Yeats, of Hauptmann and of himself. "Great loss. Requiescat in pace."

Olga Rudge asked after English friends: the Whighams, Peter Russell, Denis Goacher. It was a good evening. Pound was uninterested in a $\mathrm{BBC}$ radio programme I was making with D. G. Bridson, called "Ezra Pound's Provence". He disapproved of the BBC performance of his short opera, Villon. Murray Shaffer, he said, had been "inaccurate" on his music. Pound had not been to England since 1938.

I asked if Ford Madox Ford was unhappy. "No, not in his heart, though he had good reason to be." Ford had come to Rapallo a few times. "Who did his daughter marry?"

1 EP wrote to a friend: "Have recovered considerably during the last two weeks, might even hope by drastic cutting out of rubbish to make a poem of my Cantos. // Young Alexander has been irritated into doing better with anglo saxon ..." (Thanks to David Moody, Pound's biographer, for this information.) In 1966, Pound wrote: "Dear Alexander / thank you for excellent work \& result in 'Earliest English Poems' / I have just received the book and read the introduction. Yours cordially, Ezra Pound." Olga Rudge wrote that he was "Reading 'The E.E.P' with great pleasure - Read poems out loud last night - nearly an hour ...” 
Olga Rudge was learning to cook. Pound is said to have been a good cook; he has a line in the Cantos "Some cook, some do not cook, some things cannot be altered."

OR: "Am I improving?"

EP: "You complicate things sometimes" (smile).

OR: "All right Ezra, draught Ezra, coat Ezra, woollen hat, Ezra, why won't you come out, Ezra, What shall I do, Ezra?" (All this from the kitchen).

EP: "What do you think of Lowell? I read him more than I read some others. Imitations." I said I liked Lowell, but that he flexed his muscles too much. Grunt.

I found that EP did not know Ford's book Provence. I told him that I thought that his line, in The Cantos, that Ford's conversation consisted "in res not in verba" did not strike me as obviously true. He fell back on ben trovato.

Had he visited Greece? He thought he would never get there. I suggested flying. EP (heavily): "I have only once been ... in an airplane." (That was when he was flown back to face trial in Washington in 1945.)

MA: "Do you read Eliot's later work with as much pleasure as his earlier?"

EP: "If you can take your pleasures sadly enough ... I don't think it amounts to very much." (So when Pound, after Eliot's death, urged us to "READ HIM", he probably meant the early work, not Four Quartets.) I defended Eliot, and confessed that Williams wrote so much that "I couldn't like it all - bad and good so mixed up. Cummings too."

On Eliot: "If your grandfather has founded a university, the cultural level in the household is higher than if you come from nowhere."

"I set out to be more cheerful" (than TSE).

Did he read books about himself? EP: "Kenner. Gnomon got it all.” I defended Milton's prose. "No." 
MA: "You don't change your opinions."

EP: "No, that's not true."

He did not refer to the war or to Washington.

"Good bye, sir."

Olga: "Come and see us in the Spring." She was glad to hear me talk, my voice reminded her of Adrian Stokes.

The second visit was also in the summer, in 1963, from Perugia where I was learning Italian, and also for two days. I came to the little house above Rapallo with a friend, Martin Gray, riding on the back of Martin's Lambretta: a two-day trip, with an uncomfortable night on a park bench in Florence. There were other visitors, friends of Olga's. EP's health was better. "I sleep like a hog" and that he felt better with every fortnight that passes: ogni quindici migliore.

My impression was that Pound did not find the company interesting. A talkative musical friend of Olga's was visiting. Olga tried to get people into the house in the hope - rarely fulfilled - of stimulating EP. It was company for Olga too, of course.

MA: "How are you keeping?"

A: "I get stupider and stupider."

Q: "Do you get enough time to yourself?"

A: "There's a fairly steady stream [of visitors]."

Q: "Are there any more Cantos?"

A: "There are some fragments. I can't make sense of them and I doubt if anyone else will." (As in 1962.)

"I never studied anything seriously.... I know a little about the Malatesta.... When I got to the end of the $7^{\text {th }}$ Canto I had no idea how to proceed.... I loathe fish.... Of course, if you know nothing about books and you know nothing about life ... if you're completely ignorant in both fields.... Tempus loquendi, tempus tacendi."

Such laconic dicta were the chosen mode of Pound's isolated deliverances. 
These visits to the poet and translator whom I had so much admired had turned out well enough, but I resolved not to trouble Pound again. I had learned from his writings, and I was now learning from his silence. I saw that Pound (unlike Olga Rudge) did not want visitors; I became conscious of the pain that he had caused his family, and supposed that he too was uncomfortably conscious of it.

\section{$* * *$}

In the summers of 1964 and 1965 I spent holidays at Brunnenburg, staying with Peter and Jean Whigham and their young family, who had moved there from Sussex. My former teacher was near the end of his translation of Catullus, which was also to appear in Penguin. The Whighams were in EP's former flat at the castle, with the furniture he had made himself, Gaudier-Brzeskas on the walls and the giant Gaudier head of Pound taking up a sizeable chunk of the castle's little triangular garden above the valley. During these holidays I met Dorothy Pound, Pound's daughter Mary, and her husband, Prince Boris de Rachewiltz, whose family owned the castle, a ruin when they bought it. (The Whighams' flat did not have hot water; this was common in Italy at that time.) There I also met Noel Stock, an Australian disciple who was sorting out Pound's papers and would later write the first life of Pound. Also resident was the American philosopher, Daniel Cory, who had been George Santayana's secretary, and others, including the exotic Peter Goulart, a Russian who had been a Tibetan Buddhist priest. Goulart, on being told by his editor that the proofs of a book of his were too long by a few pages and that they needed to be cut, cut out the pages with a pair of scissors. I was later to meet Dorothy's son, Omar, and in London saw Dorothy, and Agnes Bedford, a friend of Pound's from Kensington days.

At our first meeting at Brunnenburg Mrs Pound asked if I was reading Céline. This French writer was unknown to me; I was reading P.G. Wodehouse. Dorothy, an English lady with a very straight back, liked my translation of the Old English poem, "The Wife's Complaint". The situation in that poem must have reminded her of the time when she had lived in a basement in Washington to be near her husband in St Elizabeths. I still have one of the watercolours Dorothy gave me.

Pound was absent. Only after I had read Stock's 1970 biography did I have a reasonably full account of Pound's life and of the public record. From the texts of his wartime broadcasts on Rome Radio, I had to accept 
what had previously been hearsay, that Pound had indeed been anti-Semitic, and grossly so. (To read the selection of the broadcasts edited by Doob is a dismaying experience. Some, those on literary topics, are excellent. Others break down into abusive incoherence.)

$* * *$

Westminster Abbey, January 1965. I greeted Ezra Pound after Eliot's memorial service in Westminster Abbey, one of the three people who did so. After the service I saw Pound, standing in a long black coat, with a cane, outside the west door, in a space apart from the many others there. Seeing that no one approached him, I did so, gave my name, shook his hand and retired. He stood there on that cold day for several more minutes till two men approached him. The first said "My name is Stephen Spender. I came to see you in St Elizabeths. I don't know if you will remember me." Pound: "No". The other man then identified himself as Cleanth Brooks, a literary critic then serving as the cultural attaché at the US Embassy. He read out a tribute to Pound. In reply, Pound said nothing.

Eventually a black car drew up, one which Olga Rudge had arranged. Pound got in with her. As the car drove away a man started to bang on the car. I asked the man what he thought he was doing. He said that he had handed Pound a card as Pound entered the Abbey, requesting an interview afterward. He was indignant. So was I. I said it was natural that Pound did not want to give an interview after attending a memorial service for one of his oldest, closest and most loyal friends. The journalist could not see this. We argued. He had interviewed other poets in the Sunday Telegraph, and Pound was to be the third interview in a series. Pound had let him down, it would be bad for his career!

He thought of a remedy, however. A fictitious "interview" duly appeared in the Sunday Telegraph, concocted out of what I had said, padded out with remarks Pound was supposed to have uttered, including such un-American vacuities as "Eliot weather, this". The lying journalist had made up the whole thing. I rang up the paper several times to protest, but to no avail. Eventually, however, the paper printed an apology, after a letter from Stephen Spender. Years later, in the late 1990s, I was seated opposite Mrs Eliot at a luncheon at which the T.S. Eliot 
Poetry Prize was awarded to the Australian poet Les Murray. I told Mrs Eliot about my experience outside Westminster Abbey, and she told me that after her husband's memorial service was announced, Pound had written from Italy to ask "whether if he came to London, he would be 'received'." She had welcomed him to her flat and had tried to cheer him up. (In the depression and perhaps remorse of his last decade he often expressed profound doubts as to whether his work had any value. Pound is not the only writer to have expressed such doubts. But that he should feel so disgraced that he needed to write thus to the widow of his old friend I find remarkable.)

Venice. A year or two later, on holiday in Venice, I was sitting on the Zattere having a coffee, and looked up to see Pound walking with Olga, between my café and the Giudecca canal. I went up to present my respects, again intending to retire, as I had outside Westminster Abbey. But Olga Rudge took my arm and insisted that I come back with them to her house in nearby San Gregorio, in the hope of amusing the old man (a hope not fulfilled). We ate a couple of meals out at restaurants. Pound said very little, though he had not lost his wits. He was listening, but it was still tempus tacendi. At Olga's house I met Joan Fitzgerald, the American sculptor, a loyal friend and supporter of the frail poet and his strong companion. Joan, who had made a fine head of Pound, became a family friend, and we often met later, but she has since sold up in Venice and gone back to the USA.

Olga Rudge wanted to keep Ezra amused, anything to interest him or draw him out. He half resented it. She talked a lot. I remember her saying that when they went to England to Eliot's memorial service, their bags must have been opened. Her remarks were usually followed by capito?! One was expected to agree. She was always trying to get Pound to talk, or to eat, or to drink, which met with resistance.

\section{***}

What does Pound mean today, to me and to others in Britain? My critical responses to these questions are found in the two books I mentioned above, Poetic Achievement and Sons of Ezra. I do not withdraw from any of the positive judgements offered in those books, on the contrary; though I now have less patience with Pound's crankier moments. What little I can now add is largely historical. 
Poetic Achievement took some time to write. I had undertaken it because Pound was so little understood in Britain, and I had long admired his poetry and his translations. My friend Martin Gray advised me to write it, "to get Pound out of your system", although the resulting book seems free of any Oedipal impulse. British interest in Pound and poetic modernism had re-awakened in the middle 1960 s, a period more open to experiment than the post-war years. A sign of this change was the acceptance by Penguin Classics of the poetic translations from Old English which I offered to them, and of Catullus offered to them by Peter Whigham. Penguin later persuaded me to translate Beowulf. Verse translation of the classics was common in the USA, but these Penguin commissions were far from the "readable modern English prose" which had been the declared stylistic policy of E.V. Rieu, founder editor of Penguin Classics. Rieu had graduated from Oxford in classics in 1908, the year of the arrival in London of Ezra Pound, whom Rieu described as his bête noir.

The Poetic Achievement was very favourably reviewed by over thirty critics, some of them well-known, and the book won a prize. Sales, however, were feeble. And by the time Sons of Ezra was completed, in the mid 1990s, Pound's reputation had sunk in Britain. Up to about 1970, too little interest had been taken in Pound's politics; after 1970, too much. A pity, for his poetry is more interesting than his politics and his economics.

The measure of artistic autonomy formerly extended to nearly all literature was suspended, and Pound, blacklisted as pro-Fascist and (particularly in the USA) as anti-Semitic, went unread. Nor was he likely to appeal to feminist critics. For this reason, Sons of Ezra, a set of commissioned testimonies from modern British poets, including Edwin Morgan, Charles Tomlinson, Donald Davie, Douglas Dunn and Robert Crawford, was declined by a series of British publishers, beginning with Faber and Carcanet, both of whom had long been sympathetic to Pound. Eventually the book was accepted by a Dutch academic press. It was received in silence and sank without comment. As for a wider legacy, Pound had had a flutter of revival in the 1960s, for example with Charles Tomlinson and Donald Davie and in some experimental little magazines with American sympathies, but I do not see significant traces of Pound's direct influence among acknowledged British poets now writing, even though his historic advocacy of verbal economy certainly helped to tighten things up. The same, however, might be said of T.S. Eliot, greatly as he was appreciated (partly for his criticism) for several 
decades. Now, however, Pound seems to be becoming of interest, as a liberating and modernising example, in non-Anglophone countries, especially in China, Japan, South America and Russia.

One reason that Sons of Ezra was not published in the UK and that Poetic Achievement did not sell, had little to do with Pound himself or with his more objectionable political and economic opinions. Modernist poetry itself, attacked by Philip Larkin and Kingsley Amis in the 1960s, had by the 1990s become of diminishing interest to what remained of that part of the middlebrow reading public which read poetry. And classic literature, and poetry itself - even lyric poetry - had fewer readers in England than in the 1960s. I became aware, in the process of preparing to write a History of English Literature, that the general reading public, which before the First World War had had a broad liking for the simpler kinds of poetry, had begun to lose interest in poetry after that war. One reason for this decline, if not the chief reason, was that modernist poetry was too demanding, too intellectual, too learned, too "elitist". It may now be supposed that poetry has always been a minority interest. That is not true. Historically, verse has been widely popular, and was so in England until about a century ago. Modernist poetry, however, may be studied in universities, but it is not recited. An avant-garde is supposed to lead an army; this one left the army behind. That is not the fault of Pound and Eliot, though they have been blamed for it. The causes of the decline of the popularity of poetry are not personal but cultural and general, and lie deeper. 